\title{
A Phenomenological Study: The Impacts of Developing Phonetic Awareness through Technological Resources on English Language Learners' (ELL) Communicative Competences
}

\author{
Paolo Fabre-Merchán ${ }^{1}$, Gabriela Torres-Jara ${ }^{1}$, Francisco Andrade-Dominguez ${ }^{1}$, Ma. José Ortiz-Zurita ${ }^{1}$ \& \\ Patricio Alvarez-Muñoz ${ }^{1}$ \\ ${ }^{1}$ Universidad Estatal de Milagro, Ecuador \\ Corresponding: Paolo Fabre-Merchán, Universidad Estatal de Milagro, Ecuador. E-mail: pfabrem@unemi.edu.ec
}

Received: September 20, 2017 Accepted: November 6, 2017 Online Published: November 8, 2017

doi: $10.5539 /$ elt.v10n12p83

URL: http://doi.org/10.5539/elt.v10n12p83

\begin{abstract}
Throughout our experience within the English Language Teaching (ELT) field and while acquiring a second language in English a Foreign Language (EFL) and English as a Second Language (ESL) settings, we have noticed that one of the main perceived challenges for English Language Learners (ELLs) is to effectively communicate. Most of the time, this issue comes from the concern or fear to mispronounce any word, considering that English manages some variations on its phonetic alphabet, which differs from other languages. Therefore, it becomes necessary for ELLs the acquisition of English phonemic awareness to improve their pronunciation, fluency, and confidence when orally communicating in English. Basing on the interlanguage hypothesis, phonemic awareness, English phonology theories, and Information and Communication Technology (ICT) tools and resources, this study aims to analyze: a.) to what extend does phonemic awareness development influence on students' communication skills? b.) How effective is the implementation of technology to develop phonemic awareness? To do so, a phenomenological study, based on the constructivism epistemology, was conducted including a deep revision of the existed literature, various studies previously applied, and the researchers' experience within the teaching and professional field to examine the impacts of developing phonetic awareness through technological resources on English language learners' (ELL) communicative competences.
\end{abstract}

Keywords: English language teaching, phonetic awareness, communicative competences, technological resources, pronunciation

\section{Introduction}

One of the most relevant challenges when teaching English as a foreign language (EFL) is the lack of opportunities that students have to interact with the reality, which limits them when achieving a high level of language proficiency and communicative abilities. Pronunciation is one of the major aspects of the language that is affected, creating some fear and anxiety on students when interacting with others through oral means. Considering the Ecuadorian perspective and some studies that have demonstrated the positive impacts that technology has produced on EFL classroom in terms of motivation and exposure to real language context (Ellis \& Shintani, 2014), ICT resources and the development of phonemic awareness become imperative to support students in order to enhance their English pronunciation and communicative skills. Technology helps teachers to create learning conditions that promote the development of phonemic awareness through real exposure and interaction with native English speakers and real English sounds. This study main objective is to support EFL teachers to guide students to overcome the interlanguage issues that do not allow them to acquire a high level of English proficiency due to bad previous academic and linguistic experiences and poor interaction with real language with native English speakers.

\subsection{Interlanguage Hypothesis}

Interlanguage is "an internal system of rules that was independent of both, the learners' L1 and the target language, and which evolved gradually over time" (Ellis \& Shintani, 2014, p. 7). That is, it involves unique language features created by each student that allow them to communicate meaning, having their native language as a foundation to generate second language structures. This is also considered as the version of English that ELL used in the process of acquiring the language with some variable system of rules and pronunciation (Freeman \& Freeman, 2011). 


\subsection{Interlanguage Hypothesis: Advantages and Limitations}

One of the most relevant advantages of interlanguage is that it is a learning strategy that supports students to develop cognitive abilities (Ellis \& Shintani, 2014). When students do not have the vocabulary or English proficiency level to clearly express their ideas and thoughts they use their native language and apply paraphrasing, word-coinage, code switching, as alternative ways to communicate (Ellis \& Shintani, 2014, p. 7). On the other hand, as interlanguage changes all the time it can become a fossilized language when teachers do not set the conditions to enhance it (Yule, 2010). Thus, it is important that teachers focus their instruction on activities that support students to develop phonemic awareness, which permit students to address the interlanguage issues by enhancing their English level proficiency.

\subsection{Ecuadorian Context}

According to the new English curriculum guidelines, Ecuadorian students develop communicative and pragmatic linguistic abilities that allow them to achieve the B1 level according to CEFR standards when they graduate from high school. Considering that Ecuador is a No-English speaker country, students have poor opportunities to be exposed to real pronunciation and language variations of native English speakers. So, EFL students acquire a poor English pronunciation, having issues when pronouncing some phonemes that are exclusive to English language such as $/ \partial /$ and $/ \int /$. Moreover, this situation has guided students to produce their own version of those phonemes (interlanguage), which most of the time create misunderstanding when they are trying to convey information. The lack of phonemic awareness limits them to develop communicative competences to orally produce the language, which according to Ehri et al. (2011), it helps students to differentiate between certain phonemes such as / d / and / $\theta$ / (Ehri et al., 2011).

\subsection{Phonemic Awareness}

Phonemic awareness refers to the ability to understand that words can be break down into smaller individual units and how to correctly pronounce each one (Goldenberg et al., 2014). It is also consider as the ability to manipulate individual phonemes, blending, segmentation, and deletion (Ehri et al., 2001). In this sense, it is essential that ELLs develop phonemic awareness "to understand the relation between printed letter and speech sounds" (Bishop \& Bishop, 1999, p. 9) so that they can be capable of producing English sounds similar to native English speakers. As a starting point, it is important that students gain some knowledge of the characteristics of English phonology.

\subsection{Developing Phonemic Awareness: Characteristics of English Phonology}

Previous to study the characteristics of English phonology it is essential to have a clear picture of the process of producing sounds (Freeman \& Freeman, 2014). It is also necessary to have some knowledge about the physiology of speech production (Figure 1), which helps EFL students to know in which specific place and how native English speakers produce individual sounds. At this point, it is essential to mention that English language includes a variety of exclusive new consonants that differs from Spanish.

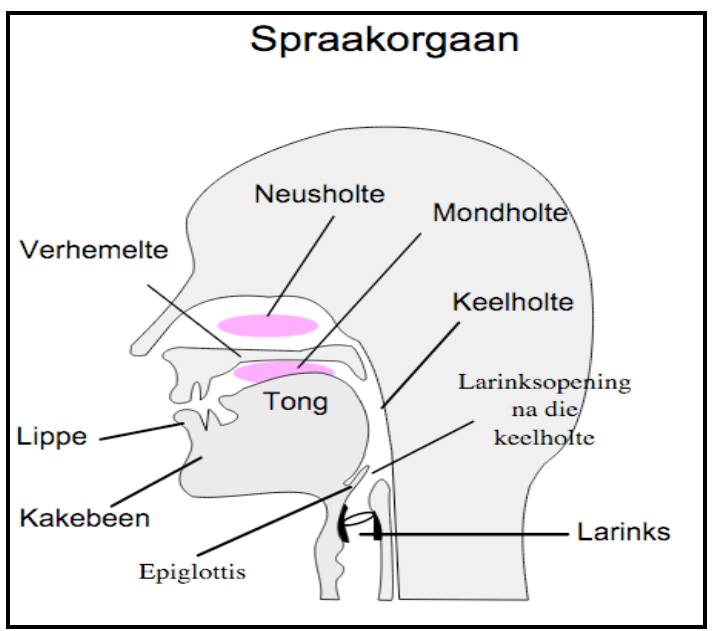

Figure 1

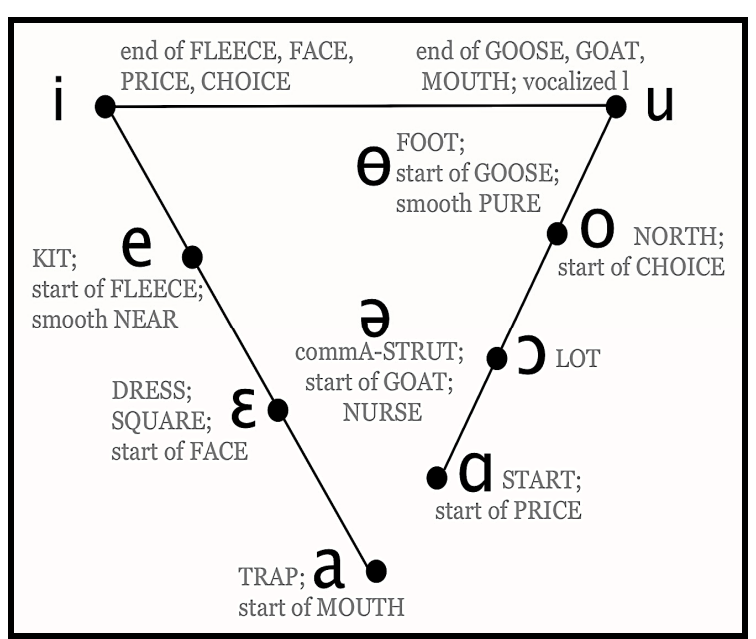

Figure 2

English Consonants Categories: consonants, in English, are produced by restricting or stopping the flow of air stream as it passes through the vocal tract (D. E. Freeman \& Y. S. Freeman, 2014). This helps linguistics to describe and to categorize the consonants by telling where and how the air is constricted. English consonants are categorized according to: manner of articulation (Table 1), place of articulation (Table 2) and, voicing (Table 3). 
Table 1. Manner of articulation

\begin{tabular}{lll}
\hline Category & Description & Consonant \\
\hline $\begin{array}{l}\text { Stop } \\
\text { Nasal }\end{array}$ & $\begin{array}{l}\text { Block airflow } \\
\text { Blocking the air in the oral cavity and lowering the velum so } \\
\text { that the airflow pass through the nasal cavity }\end{array}$ & $\mathrm{m}, \mathrm{n}, \mathrm{g}, \mathrm{b}, \mathrm{d}, \mathrm{g}$ \\
Fricative & $\begin{array}{l}\text { Partially stop oral cavity } \\
\text { Affricative }\end{array}$ & $\mathrm{f}, \mathrm{\theta}, \mathrm{s}, \int, \mathrm{h}, \mathrm{v}, \mathrm{\partial}, \mathrm{z}, \mathrm{z}$ \\
Liquids & $\begin{array}{l}\text { Stop the air and then releasing it with some friction } \\
\text { Curling the tongue tip up and back slightly and then the air }\end{array}$ & $\mathrm{d}, \mathrm{d}, \mathrm{t}$ \\
goes through the side & Most vowels-like consonants & $\mathrm{j}, \mathrm{w}$ \\
\hline
\end{tabular}

Source: Adapted from: Yule, G. (2010). The study of language. New York: Cambridge University Press.

Table 2. Place of articulation

\begin{tabular}{|c|c|c|}
\hline Category & Description & Consonant \\
\hline Bilabial & Sounds formed using both, upper and lower lips & $\mathrm{p}, \mathrm{b}, \mathrm{m}$ \\
\hline Labiodental & Sounds are produced using the upper teeth and the lower lip & $\mathrm{f}, \mathrm{v}$ \\
\hline Interdental & Sounds formed putting the tongue between the upper front teeth & ð, $\theta$ \\
\hline Alveolar & $\begin{array}{l}\text { sounds formed with the front part of the tongue on the right } \\
\text { alveolar ridge }\end{array}$ & $\begin{array}{l}\mathrm{t}, \mathrm{d}, \mathrm{n}, \mathrm{s}, \mathrm{z}, \mathrm{d}, \mathrm{l}, \int, 3 \\
\mathrm{~d} 3, \mathrm{t} \int\end{array}$ \\
\hline Palatal & $\begin{array}{l}\text { Sounds are produced behind the alveolar ridge by raising the } \\
\text { tongue to the palate }\end{array}$ & $\mathrm{j}$ \\
\hline Velar & Sound formed by raising the back of the tongue to the velum & $\mathrm{k}, \mathrm{g}, \mathrm{y}, \mathrm{w}$ \\
\hline Glottal & $\begin{array}{l}\text { Sounds are produced with no active use of the tongue and others } \\
\text { parts of the mouth }\end{array}$ & $\mathrm{h}$ \\
\hline
\end{tabular}

Source: Adapted from: Yule, G. (2010). The study of language. New York: Cambridge University Press.

Table 3. Voicing

\begin{tabular}{lll}
\hline Category & Description & Consonant \\
\hline Voiced & The vocal cores vibrate when pronouncing them & $\mathrm{b}, \mathrm{d}, \mathrm{g}, \mathrm{m}, \mathrm{n}, \mathrm{y}, \mathrm{v}, \mathrm{d}, \mathrm{z}, \mathrm{z}, \mathrm{d}, \mathrm{l}, \mathrm{j}$, \\
Voiceless & The vocal cores do not vibrate when pronouncing them & p. t, $\mathrm{k}, \mathrm{f}, \mathrm{\theta}, \mathrm{s}, \mathrm{f}, \mathrm{h}, \mathrm{d} 3, \mathrm{t} \int$
\end{tabular}

Source: Adapted from: Yule, G. (2010). The study of language. New York: Cambridge University Press.

English vowels: similar to consonants, English has more vowels that Spanish see (Figure 2), which create challenges for Spanish speakers when pronouncing them since English contains several variations of the same vowel.

\subsection{Impacts of Developing Phonemic Awareness on Oral Communication}

Some research has demonstrated the positive impacts on students' motivation to use the language orally, and that phonemic awareness development helps students to enhance their pronunciation. For instance, Bishop and Bishop (1996) demonstrated that EFL students enhance their English pronunciation when they are aware of the difference between their native language and English, which is possible when they acquire phonemic awareness. In addition, Goldenberg et al. (2015) conducted a research with Spanish speakers and demonstrated that students increase their motivation to orally interact in English when they acquire a good English pronunciation. That is, ELLs improve their communicative competences when they have some knowledge of the phonemic features that align language. This supports students to acquire a better pronunciation, similar to native English speakers by understanding where and how each phoneme is pronounced. 


\subsection{Technological Resources to Develop Phonemic Awareness}

The use of technology has demonstrated positive impacts on students' learning and language acquisition when working in EFL setting; moreover, Ruan (2015) and Fabre, Boroto, and Soto (2016) stated that the use of different input modals and medium through multimedia have great impacts on EFL comprehension as well. Having in mind that we are living in a technological era and that students love technology, teachers should take advantage of it in order to implement activities that increase students' motivation and commitment, considering that learning environment strongly influence students' motivation and commitment to work, which positively impact on productivity and quality (Fabre \& Boroto, 2017).

Advantages of Using Technology: one of the advantages of applying technological resources in classroom is that it fosters autonomy on students through an active process of guidance and encouragement, providing students opportunities to be exposed to authentic English native speaker pronunciation. Shah and Freedman (2003) also discussed a number of benefits of using phonological web tools and apps in learning environments, including: (1) promoting learning by providing an external representation of the information; (2) deeper processing of information; and (3) maintaining learner attention by making the information more attractive and motivating. In this sense, the "Sounds: pronunciation app" has helped EFL students to acquire the correct pronunciation of the each phoneme (Ruan, 2015). Moreover, Shah and Freedman (2003) provided some web tools such like "International Phonetic Alphabet" as a great educational tool to promote the acquisition of a second language through the development of phonemic awareness.

\section{The Study}

A phenomenological study, based on a constructivism epistemology, was conducted to analyze the impacts of developing phonetic awareness on English Language Learners' (ELL) communicative skills in Ecuador through a proposal that aims to introduce some digital resources to build phonemic awareness on ELLs. The analysis of the data includes a deep revision of the existed literature, the results of some previous studies, and the vast researchers' experience within the teaching and professional field in diverse levels of education, starting from middle school to higher education in two main universities in Ecuador, Universidad Estatal de Guayaquil and Universidad Estatal de Milagro

\section{Discussion}

Interlanguage hypothesis is considered as a strong learning strategy, supporting students to look for alternatives such as the use of paraphrasing or cognate to clearly express their thoughts and ideas. Interlanguage becomes imperative in the development of a foreign language to avoid fossilization. It means that interlanguage supports students to continue developing their communicative competences, which increase their opportunities to achieve high English language proficiency. Thus, it is essential that teachers foster the application of strategies that allow students to directly or indirectly acquire phonemic awareness, which has been demonstrated as an effective tool to enhance pronunciation and to increase motivation when interacting in conversations.

Phonemic awareness includes abilities to use unique sounds, which are exclusive to English language, as well as some knowledge about how and where each sound needs to be pronounced. Additionally, technology helps teachers to create conditions that increase students' motivation as well as authenticity to their classes while exposing students to real English situations, giving them access to conversations and interaction with native English speakers, and guiding students to achieve communicative competences. Virtual platforms such as: YouTube, broadcast, and TED videos provide students with opportunities to experience the English language in authentic settings and "Sounds: pronunciation app" and "International Phonetic Alphabet" are great phonemic resources to acquire the correct pronunciation of each sound.

As a starting point, it is required to conduct some professional development sessions with teachers in order to explain them how to manage the websites and apps

\section{Conclusion}

The fear of orally interacting using a foreign language is a palpable issue on ELLs within the ELT. So, the necessity to overcome this situation becomes imperative to effectively communicate and to achieve a high level of English proficiency. The acquisition of phonemic awareness is essential to improve ELLs' pronunciation and communicative abilities, especially in EFL context where students have limited access to interaction with native English speakers. Additionally, technological resources have broken some boundaries in terms of access, providing people around the world direct contact with the English language and its phonemical alphabet in real time and settings.

It has been observed and demonstrated that the development of phonemic awareness has a positive effect on 
students' communicative competences and pronunciation, increasing their confidence to orally interact in real-world setting. Furthermore, technology is an effective tool to exposure students to language used in non-English speaking countries.

This paper is the base towards taking advantage of the technological resources to enhance communicative skills. New research is necessary to examine the impact of developing phonemic awareness on students' academic achievement and not only on their communicative skills. This paper guides researchers to go deeper on the linguistic area, considering it as an impacting method to enhance English teaching, students' levels of proficiency, and scores on standardized test especially in countries where English is not the main language, such as Ecuador.

\section{References}

Bishop, A., \& Bishop, S. (1996). Teaching phonics, phonemic awareness and word recognition. Huntington Beach: Teachers Created Materials. Inc.

Ehri, L., Nunes, S., Willows, D., Schuster, B. V., Yaghoub-Zadeh, Z., \& Shanahan, T. (2001). Phonemic awareness instruction helps children learn to read: Evidence from the Nation.

Ellis, R., \& Shintani, N. (2014). Instructed second language acquisition. In exploring language pedagogy through second acquisition research. New York: Routledge.

Fabre, P., Boroto, J., \& Soto, S. (2016). Approaches to EFL teaching: Curriculum, Instruction, Assessment, and Technology 7. Editorial de la Universidad Técnica de Machala: Ecuador

Fabre, P., \& Boroto, J. (2017). A motivated student is a productive learner. INTED2017 Proceeding, 7772-7780. https://doi.org/10.21125/inted.2017.1813

Freeman, D. E., \& Freeman, Y. S. (2014). Essential Linguistics: What teachers need to know to teach ESL, reading, spelling, and grammar. Portsmouth, NH: Heinemann.

Goldenberg, C., Tolar, T., Reese, L., Francis, D., \& Mej1'a-Arauz, R. (2014). How important is to teach phonemic awareness to children learning to read in Spanish. American Educational Research Journal, 51(3), 604-633. https://doi.org/10.3102/0002831214529082

Ruan, X. (2015). The role of multimodal in Chinese EFL students' autonomous listening comprehension \& multiliteracies. Theory and Practice in Language Studies, 5(3), 549-554. https://doi.org/10.17507/tpls.0503.14

Shah, P., \& Freedman, E. (2003). Visuospatial thinking in e-learning. Journal of Educational Computing Research, 29, 315-324. https://doi.org/10.2190/QYVJ-Q59L-VE7C-EHUV

Yule, G. (2010). The study of language. New York: Cambridge University Press. https://doi.org/10.1017/CBO9780511757754

\section{Copyrights}

Copyright for this article is retained by the author(s), with first publication rights granted to the journal.

This is an open-access article distributed under the terms and conditions of the Creative Commons Attribution license (http://creativecommons.org/licenses/by/4.0/). 